Developments in American Politics 3 
Developments titles available from Macmillan

Patrick Dunleavy, Andrew Gamble, Ian Holliday and Gillian Peele (eds) DEVELOPMENTS IN BRITISH POLITICS 5

Peter A. Hall, Jack Hayward and Howard Machin (eds) DEVELOPMENTS IN FRENCH POLITICS (Revised Edition)

Gillian Peele, Christopher Bailey, Bruce Cain and B. Guy Peters (eds) DEVELOPMENTS IN AMERICAN POLITICS 3

Martin Rhodes, Paul Heywood and Vincent Wright (eds) DEVELOPMENTS IN WEST EUROPEAN POLITICS

Gordon Smith, William E. Paterson and Stephen Padgett (eds) DEVELOPMENTS IN GERMAN POLITICS 2

Stephen White, Judy Batt and Paul Lewis (eds) DEVELOPMENTS IN CENTRAL AND EAST EUROPEAN POLITICS 2

Stephen White, Alex Pravda and Zvi Gitelman (eds) DEVELOPMENTS IN RUSSIAN AND POST-SOVIET POLITICS (Third Edition)

If you have any comments or suggestions regarding this list or other Developments titles, please write to Steven Kennedy, Publishing Director, Macmillan Press Ltd, Houndmills, Basingstoke RG21 6XS, UK 


\section{Developments in American Politics 3}

Gillian Peele

Christopher J. Bailey

Bruce Cain

B. Guy Peters

Editors

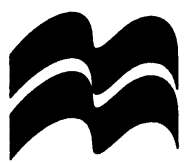


Editorial matter and selection (C) Gillian Peele, Christopher J. Bailey, Bruce Cain and B. Guy Peters 1998

Individual chapters (in order) (C) Graham Wilson, John E. Owens, Cornell W. Clayton and James Giordano, Patricia Ingraham, Christopher J. Bailey, Gillian Peele, Steve Reilly, Bruce Cain and Allison Wegner, B. Guy Peters, Dilys M. Hill, John Dumbrell, Jonathan Parker, Richard L. Engstrom, Jason F. Kirksey, Brian D. Jacobs, Philip John Davies, Alan Ware 1998

All rights reserved. No reproduction, copy or transmission of this publication may be made without written permission.

No paragraph of this publication may be reproduced, copied or transmitted save with written permission or in accordance with the provisions of the Copyright, Designs and Patents Act 1988, or under the terms of any licence permitting limited copying issued by the Copyright Licensing Agency, 90 Tottenham Court Road, London W1P 9HE.

Any person who does any unauthorised act in relation to this publication may be liable to criminal prosecution and civil claims for damages.

The authors have asserted their rights to be identified as the authors of this work in accordance with the Copyright, Designs and Patents Act 1988.

First published as Developments in American Politics 1992

Reprinted twice

Second edition 1994

Reprinted twice

Third edition 1998

Published by

MACMILLAN PRESS LTD

Houndmills, Basingstoke, Hampshire RG21 6XS

and London

Companies and representatives

throughout the world

ISBN 978-0-333-66017-1

ISBN 978-1-349-26834-4 (eBook)

DOI 10.1007/978-1-349-26834-4

A catalogue record for this book is available from the British Library.

This book is printed on paper suitable for recycling and made from fully managed and sustained forest sources

Copy-edited and typeset by Povey-Edmondson

Tavistock and Rochdale, England 


\section{Contents}

Preface

List of Contributors

xi

List of Tables, Figures and Maps

xiii

List of Abbreviations and Acronyms

$\mathrm{xv}$

Map of the United States of America

xvii

xxii

1 Introduction: The United States in the 1990s

Gillian Peele, Christopher J. Bailey, Bruce Cain and B. Guy Peters

\section{PART ONE THE INSTITUTIONAL FRAMEWORK}

2 The Presidency Graham Wilson 19

A shrunken presidency? 19

Perspectives on the presidency 20

The significance of Clinton 23

Dimensions of disaster and triumph $\quad 26$

Rebuilding a reputation: $\quad 31$

The importance of formal powers 31

A rhetorical presidency $\quad 32$

The Executive Branch presidency 33

"Ours is not a presidential system" $\quad 37$

Implications for future presidents $\quad 39$

3 Congress and Partisan Change John E. Owens 42

Agenda change and partisan change $\quad 42$

Institutional Change $\quad 45$

Conditional party government $\quad 46$

Republican Party government in the House 48

The Contract With America - a party manifesto $\quad 48$

More centralized leadership $\quad 49$

Party control and committees 49

Centralization within committees 51

Enacting the Contract 52

After the Contract 53 
Change in the Senate 55

Enacting the Contract 55

The individualistic Senate 56

Dole and the Senate Republicans $\quad 57$

Making the Senate (a little bit) more like the House

A more combative leadership? 62

The limits of institutional change $\quad 64$

Explaining institutional change $\quad 65$

Conclusions $\quad 69$

4 The Supreme Court and the Constitution

Cornell W. Clayton and James Giordano 71

The Court's legal and political context $\quad 72$

Judicial decision-making $\quad 75$

The right to privacy and abortion $\quad 80$

Equal protection and affirmative action $\quad 82$

$\begin{array}{ll}\text { Church and state } & 84\end{array}$

Free expression $\quad 86$

The separation of powers and federalism $\quad 87$

The Justice Department and Clinton's legal policy $\quad 88$

Lower-Court appointments $\quad 94$

Conclusions $\quad 95$

5 The Federal Bureaucracy Patricia Ingraham 97

Assessment of the role and effectiveness of

bureaucratic institutions $\quad 97$

"Reinventing government" 100

Downsizing the American federal government 103

$\begin{array}{ll}\text { The administrative implications of policy devolution } & 107\end{array}$

The Government Performance and Results Act (1993) 110

Performance-based organizations 112

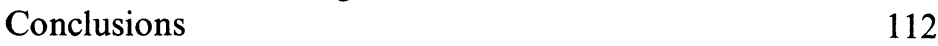

6 The Changing Federal System Christopher J. Bailey 114 The dynamics of federalism 116

The politics of contemporary federalism 119

The "Devolution Revolution" 125

Conclusions $\quad 132$ 


\section{PART TWO DYNAMICS}

7 Political Parties Gillian Peele 137

An anti-party environment? 138

Perot and the third-party phenomenon $\quad 140$

Ideology, issues, and the party response 141

The Democratic Party 143

The Republican Party 148

Republican presidential politics 151

The Republican Party in Congress $\quad 152$

Republican governors $\quad 155$

Party organization $\quad 156$

Democratic organization $\quad 156$

Republican organization $\quad 157$

Candidates, campaigns, and money 158

$\begin{array}{ll}\text { Conclusions } & 160\end{array}$

8 Interest Groups in National Politics Steve Reilly 162

Interest groups and organized interests 162

Organized interests in the 1990s 164

Business groups 164

Labor unions 166

Other membership groups $\quad 169$

Think-tanks 173

Trends in strategy and tactics 175

$\begin{array}{ll}\text { Coalitions } & 176\end{array}$

Organized interests and campaign finance 178

The Internet $\quad 180$

$\begin{array}{ll}\text { Conclusions } & 182\end{array}$

9 Electoral Politics Bruce Cain and Allison Wegner 183

Volatility examined $\quad 184$

Trends in state government 193

Republican gains and frustrations $\quad 197$

The quest to control short-term forces 201

\section{PART THREE PUBLIC POLICY}

10 Economic Policy B. Guy Peters 211

The challenges of economic policy $\quad 212$

The goals of economic policy 213 
The instruments of economic policy 215

The public household 218

Emerging issues in the economy 219

The basic paradox: doing better and feeling worse 220

Macro-performance 221

Conclusions $\quad 228$

11 Social Policy Dilys M. Hill 230

The policy climate 231

Heath care insurance for all 233

The demands for change 233

The groundwork of the plan 234

Challenges to change 236

From opposition to defeat $\quad 237$

Welfare, work, and dependency $\quad 240$

The American approach to welfare 240

Attacking poverty or attacking the poor? 243

The Clinton plan 244

The Personal Responsibility and Work Opportunity Act (1996) 246

Outputs and outcomes 248

Ending the New Deal assumptions 249

Conclusions 250

12 Foreign Policy John Dumbrell 252

The Clinton Administration and post-Cold War internationalism 253

Republicans and foreign policy 260

Defense, intelligence and trade 263

Post-Cold War foreign policy-making 267

Conclusions $\quad 271$

\section{PART FOUR CONTEMPORARY ISSUES}

13 Education Policy Jonathan Parker 277

State and local control of elementary and secondary education $\quad 279$

The limited role of the federal government 281

The role of the courts 284

Education reform 285 
Higher education $\quad 289$

Prospects for the future 290

14 Affirmative Action and the Politics of Race

Richard L. Engstrom 292

Compensatory action as policy 294

White reactions to affirmative action 295

Affirmative action as a political issue 299

Affirmative action as a legal issue $\quad 302$

The uncertain future of affirmative action 304

15 Campaign-finance Reform Jason F. Kirksey 307

The 1996 elections $\quad 308$

The presidential election $\quad 308$

"Soft" money 310

Congressional elections $\quad 312$

Independent expenditures $\quad 314$

Prospects for campaign-finance reform $\quad 315$

Campaign-finance reform opponents $\quad 317$

Congressional hearings 318

Conclusion: the structure of campaign-finance reform $\quad 318$

16 The Regional City: Governance and Competitiveness in

Pittsburgh Brian D. Jacobs 320

Cities are important $\quad 320$

Entrepreneurial cities $\quad 323$

The competitive challenge in "America's new economy" $\quad 324$

Pittsburgh: defending the base $\quad 326$

Networked governance: overcoming fragmentation $\quad 329$

Community empowerment $\quad 334$

Conclusion 336

17 The Media and U.S. Politics Philip John Davies 337

All's fair in love and war 337

The Hollywood sign: the fear and fascination of mass-media entertainment 339

Drawing a line in the sand: grandstanding against cultural threats

The media market 
Segmentation of provision $\quad 343$

The developing information environment 344

The traditional news media 346

The political campaign and the media 347

$1996 \quad 349$

Conclusions 352

PART FIVE AMERICAN POLITICS AT THE CENTURY'S END: AN OVERVIEW

18 The American Political System in Transition to a New Century Alan Ware 357

Evidence of turbulence and conflict 357

Would we have expected the 1990 s to be an era of political conflict? 363

The sources of political conflict and turbulence $\quad 364$

Antagonistic subcultures 366

The worsening position of the American worker $\quad 367$

The impact of the end of the Cold War 371

Increasing ideological cohesion in the political parties 372

The consequences of political reform in the 1970s 373

The role of individual politicians $\quad 374$

The future of the unquiet polity 376

Guide to Further Reading 383

Bibliography 387

Index $\quad 412$ 


\section{Preface}

This is the third Developments in American Politics volume. All the chapters are new and, with the exception of the editors there is a totally new group of contributors. We have been fortunate in attracting an outstanding international team of authors and a number of younger scholars of American politics to write for the book.

As in the last volume, individual authors were asked both to analyze recent developments in their area and to balance the theoretical and empirical material. They were also asked to produce chapters which would be accessible and useful to students at an early stage of studying American politics as well as stimulating to more advanced students. All authors were asked to concentrate on the contemporary American scene, but the proximity of the publication of this volume to the turn of the century has prompted us to give the Introduction and the concluding section of the book a slightly broader historical focus than in earlier volumes as a way of encouraging reflection on the significance of recent political development.

In order to make the book user-friendly to its readers around the world and to convey the color and idioms of American politics, we have used American spelling throughout and, where appropriate, the party and state of elected politicians has been included. The references to works cited in the chapters are collected together at the end of the book, and there is also a short Guide to Further Reading for each of the chapters.

The editors would like to thank our publisher Steven Kennedy for the help and encouragement he has given to this volume. We also thank our American publishers Chatham House and record with sadness the death of Ed Artinian, who did so much to improve earlier versions of the book. We also thank our anonymous referees. The editors acknowledge with gratitude the intellectual support given by their respective colleagues at the University of Oxford, the University of Keele, the University of California at Berkeley and the University of Pittsburgh. We are also especially grateful to the secretarial and support staff in our respective 


\section{xii Preface}

institutions. We also gratefully acknowledge the range of fundraising bodies which have supported our studies and especially the Mellon Trust which has done so much for American research at Oxford. A special vote of thanks goes to Elizabeth McLeish, Samuel Gregg and Teresa Curristine, all in the University of Oxford, who rendered vital and good humoured assistance at various stages in the preparation of this book. 


\section{List of Contributors}

Christopher J. Bailey is a Senior Lecturer in American Studies at Keele University.

Bruce Cain is Robson Professor of Government and Acting Director of the Institute of Governmental Studies, University of California at Berkeley.

Cornell W. Clayton is Professor of Political Science at Washington State University at Pullman.

Philip John Davies is Professor of American Studies at De Montfort University.

John Dumbrell is a Senior Lecturer in American Studies at Keele University.

Richard L. Engstrom is a Research Professor of Political Science at the University of New Orleans.

James Giordano is a doctoral candidate at Washington State University.

Dilys M. Hill is Professor of Politics at the University of Southampton.

Patricia W. Ingraham is Professor of Political Science at Syracuse University.

Brian D. Jacobs is Reader in the Faculty of Social Studies at Staffordshire University.

Jason F. Kirksey is Hannah D. Atkins Professor of Political Science at Oklahoma State University.

John E. Owens is Director of the Study of Democracy at the University of Westminster.

Jonathan Parker is a Lecturer in American Studies at Keele University.

Gillian Peele is Fellow and Tutor in Politics at Lady Margaret Hall, Oxford.

B. Guy Peters is Maurice Falk Professor of American Government at the University of Pittsburgh.

Steve Reilly is a Lecturer in International Relations at the University of Kent.

Alan Ware is Professor of Politics at Worcester College, Oxford. 
xiv List of Contributors

Allison Wegner is a doctoral candidate at the University of California at Berkeley.

Graham Wilson is Professor of Political Science at the University of Wisconsin, Madison. 


\section{List of Tables, Figures and Maps}

\section{Tables}

2.1 Presidential approval ratings since F.D.R. 28

3.1 Party control of Congress, 1900-98 43

3.2 Changing vote alignments in the House across four dimensions, 1981-96

5.1 Budget and workforce reduction in U.S. federal agencies, 1993 and $1996 \quad 105$

9.1 Independent party identification 1952-94 185

9.2 Partisan party identification, 1952-94 190

9.3 1996 vote compared to population statistics, $1995 \quad 191$

9.4 Gender and the vote, 1992 and 1996

9.5 Divided government at the state level, 1988-96 195

10.1 Economic growth of the United States and other
industrialized democracies, $1970-79$ to 1996

10.2 Unemployment rates, 1980-96 222

10.3 Inflation rates, 1980-96 222

10.4 The public deficit as a percentage of G.D.P., 1985-95 222

16.1 Regional partnership development: the "layer cake" 331

16.2 The Working Together Consortium: aims and partners

Figures

3.1 House members' changing support of four policy dimensions, 1977-94

3.2 Percentage of votes which divided the parties, 1954-97

3.3 Mean House-party support scores, 1954-97 68

9.1 Correlations between district presidential vote and House vote, 1952-96 
xvi List of Tables, Figures and Maps

9.2 Republican strength in the House, by region, 1946-96

9.3 Democratic strength in the House, by region, 1946-96

Maps

Frontispiece The United States: states and main cities excluding Alaska and Hawaii

16.1 The Pittsburgh region, including M.S.A. counties 


\section{List of Abbreviations and Acronyms}

AARP

$\mathrm{ABC}$

ACIR

ACLU

AFDC

AFL-CIO

APEC

CATS

CBS

CEOs

CSE

CETA

CIA

COS

CPI

CREF

CRS

CSRA

$\mathrm{D}$

DAETC

DHHS

DLC

DNC

DOD

DOE

DOEd

DOJ
American Association of Retired Persons

American Broadcasting Corporation

Advisory Commission on Intergovernmental

Relations

American Civil Liberties Union

Aid to Families with Dependent Children

American Federation of Labor-Congress of Industrial Organization

Asia Pacific Economic Cooperation

Conservative Action Team

Columbia Broadcasting System

Chief Executive Officers

Citizens for a Sound Economy

Comprehensive Employment Training Act

Central Intelligence Agency

Conservative Opportunity Society

Citizens for Public Integrity

Citizens for the Republic Education Fund

Congressional Research Service

Child Support Recovery Act (1988)

Democrat

Denver Area Educational Telecommunications Consortium Inc.

Department of Health and Human Services

Democratic Leadership Council

Democratic National Committee

Department of Defense

Department of Energy

Department of Education

Department of Justice 


$\begin{array}{ll}\text { DOMA } & \text { Defense of Marriage Act (1996) } \\ \text { EEOC } & \text { Equal Employment Opportunity Commission } \\ \text { EC } & \text { Empowerment Community } \\ \text { EMU } & \text { European Monetary Union } \\ \text { EPA } & \text { Environmental Protection Agency } \\ \text { ESEA } & \text { Elementary and Secondary Education Act (1965) } \\ \text { EU } & \text { European Union } \\ \text { EZ } & \text { Empowerment Zone } \\ \text { FBI } & \text { Federal Bureau of Investigation } \\ \text { FCC } & \text { Federal Communications Commission } \\ \text { FDA } & \text { Food and Drug Administration } \\ \text { FEC } & \text { Federal Election Commission } \\ \text { FECA } & \text { Federal Election Campaign Act (1971, amended } \\ & \text { 1974) } \\ \text { FEMA } & \text { Federal Emergency Management Agency } \\ \text { FY } & \text { Fiscal Year } \\ \text { GAO } & \text { General Accounting Office } \\ \text { GATT } & \text { General Agreement on Tariffs and Trade } \\ \text { GDP } & \text { Gross Domestic Product } \\ \text { GI } & \text { General Issue } \\ \text { GOP } & \text { Grand Old Party (the Republican Party) } \\ \text { GPRA } & \text { Government Performance and Results Act (1993) } \\ \text { GRS } & \text { General Revenue Sharing } \\ \text { GSA } & \text { General Services Administration } \\ \text { HMOs } & \text { Health Maintenance Organizations } \\ \text { HUD } & \text { (Department of) Housing and Urban } \\ \text { IDEA } & \text { Development } \\ \text { IRS } & \text { Individuals with Disabilities Education Act } \\ \text { IT } & \text { Internal Revenue Service } \\ \text { JOBS } & \text { Information Technology } \\ \text { JTPA } & \text { Job Opportunities and Basic Skills (program) } \\ \text { JVSVN } & \text { Job Training and Partnership Act } \\ \text { MSA } & \text { Joint Venture Silicon Valley Network } \\ \text { NAACP } & \text { Metropolitan Statistical Area } \\ \text { NAFTA } & \text { National Association for the Advancement of } \\ \text { NAM } & \text { Nolored People } \\ & \text { National Association of Manufacturers } \\ & \end{array}$




$\begin{array}{ll}\text { NAPA } & \text { National Academy of Public Administration } \\ \text { NBC } & \text { National Broadcasting Corporation } \\ \text { NCES } & \text { National Center for Educational Statistics } \\ \text { NES } & \text { National Election Study } \\ \text { NFIB } & \text { National Federation of Independent Businesses } \\ \text { NGA } & \text { National Governors' Association } \\ \text { NOW } & \text { National Organization for Women } \\ \text { NJ } & \text { New Jersey } \\ \text { NPR } & \text { National Peformance Review } \\ \text { NSF } & \text { National Science Foundation } \\ \text { OECD } & \text { Organization for Economic Cooperation and } \\ & \text { Development } \\ \text { OMB } & \text { Office of Management and Budget } \\ \text { OPM } & \text { Office of Personnel Management } \\ \text { PAC } & \text { Political Action Committee } \\ \text { PBO } & \text { Performance-Based Organization } \\ \text { PPI } & \text { Progressive Policy Institute } \\ \text { PR } & \text { proportional representation } \\ \text { R } & \text { Republican } \\ \text { R\&D } & \text { research and development } \\ \text { RCCC } & \text { Republican Congressional Campaign Committee } \\ \text { RNC } & \text { Republican National Committee } \\ \text { SAG } & \text { Speaker's Advisory Group } \\ \text { SES } & \text { Senior Executive Service } \\ \text { SME } & \text { small and medium-sized enterprise } \\ \text { SSI } & \text { Social Security Insurance } \\ \text { START } & \text { Strategic Arms Reduction Talks } \\ \text { TAFTA } & \text { Transatlantic Free Trade Agreement } \\ \text { TANF } & \text { Temporary Assistance for Needy Families } \\ \text { UDAG } & \text { Urban Development Action Grant } \\ \text { URA } & \text { Urban Redevelopment Authority (Pittsburgh) } \\ \text { UN } & \text { United Nations } \\ \text { USAID } & \text { US Agency for International Development } \\ \text { VA } & \text { (Department of) Veterans' Administration } \\ \text { VNS } & \text { Voter News Service } \\ \text { WIN } & \text { Work Incentives (program) } \\ \text { WLC } & \text { White House Legal Counsel's Office } \\ \text { WTO } & \text { World Trade Organization } \\ & \end{array}$


$\mathrm{xx}$ List of Abbreviations and Acronyms

State Abbreviations

\begin{tabular}{ll} 
Ariz. & Arizona \\
Ark. & Arkansas \\
Calif. & California \\
Colo. & Colorado \\
Conn. & Connecticut \\
D.C. & District of Columbia \\
Del. & Delaware \\
Fla. & Florida \\
Ga. & Georgia \\
Ill. & Illinois \\
Ind. & Indiana \\
Kans. & Kansas \\
Ky. & Kentucky \\
La. & Louisiana \\
Maine & Maine \\
Mass. & Massachusetts \\
Md. & Maryland \\
Mich. & Michigan \\
Minn. & Minnesota \\
Miss. & Mississippi \\
Mo. & Missouri \\
Mont. & Montana \\
N.C. & North Carolina \\
N.Dak. & North Dakota \\
Nebr. & Nebraska \\
Nev. & Nevada \\
N.H. & New Hampshire \\
N.J. & New Jersey \\
N.Mex. & New Mexico \\
N.Y. & New York \\
Okla. & Oklahoma \\
Oreg. or Ore. & Oregon \\
Pa. & Pennsylvania \\
R.I. & Rhode Island \\
S.C. & South Carolina \\
S.Dak. & South Dakota \\
Tenn. & Tennessee \\
Tex. & Texas \\
& \\
\hline
\end{tabular}


List of Abbreviations and Acronyms xxi

$\begin{array}{ll}\text { Utah } & \text { Utah } \\ \text { Va. } & \text { Virginia } \\ \text { Vt. } & \text { Vermont } \\ \text { Wash. } & \text { Washington State } \\ \text { Wis. } \text { or Wisc. } & \text { Wisconsin } \\ \text { W.Va. } & \text { West Virginia } \\ \text { Wyo. } & \text { Wyoming }\end{array}$




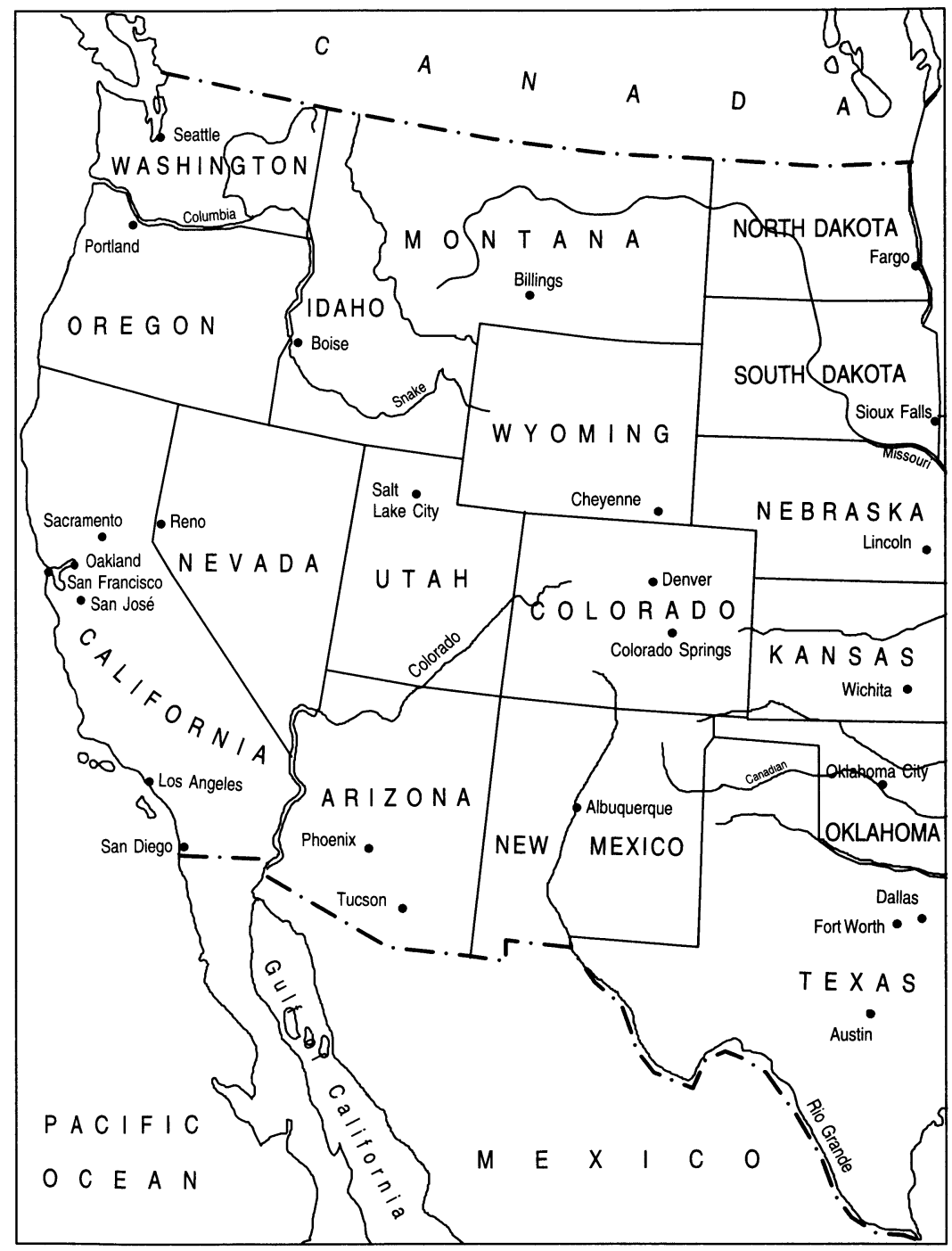

The United States of America: states and main cities 


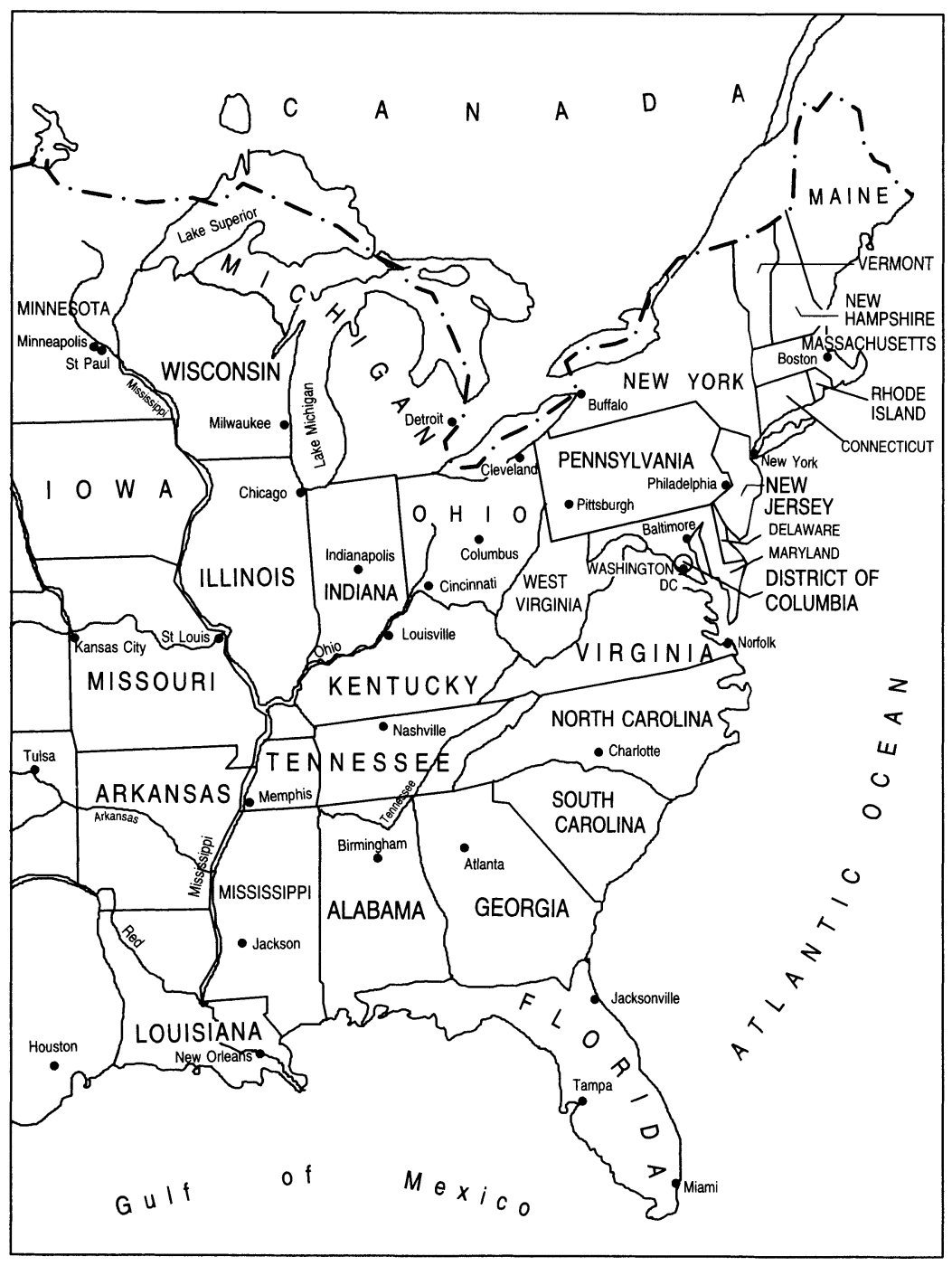

(excluding Alaska and Hawaii) 